\title{
Strategies of Local Government Units (LGUs) to improve Business Tax Collections during the Covid-19 Pandemic
}

\author{
Joaila B. Dela Cruz ${ }^{1}$, Eileen Joy S. Domingo ${ }^{2}$, Nesle G. Dungca ${ }^{3}$, Angelika Mariz F. \\ Francisco $^{4}$, Marivic DC. Gonzales ${ }^{5}$, Jocelyn B. Cruz ${ }^{6}$
}

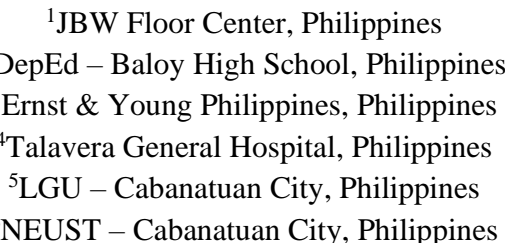

Received: 14 Jul 2021; Received in revised form: 09 Aug 2021; Accepted: 15 Aug 2021; Available online: 20 Aug 2021

\begin{abstract}
This study gave details on the strategies used by Local Government Units (LGUs) to boost business tax collection during the COVID-19 pandemic. The study's findings also revealed the impact of the Pandemic on tax collection. The survey questionnaire was employed to gather data, and the descriptive method of study was applied. During the data collection period, the respondents were limited to the available personnel of the Cabanatuan City Treasurer's Office. The key statistical techniques employed in evaluating and interpreting the research data were descriptive statistics such as weighted mean and percentages. The results demonstrated that during the pandemic, tax collection was hampered by temporary or permanent business closures, and curtailed operations resulted in lower revenue for enterprises. The LGUs can deploy a digital facility for business tax assessment and payment, which promotes taxpayer compliance and aids the government in meeting its target collections during the pandemic while following minimal health protocols. Furthermore, retaining all essential information on taxpayers, using digital platforms, assists the LGUs in disseminating information about tax dues and extensions of payment deadlines.
\end{abstract}

Keywords—Business Tax, Collections, Digital Facility, Local Government Units,Tax Revenue.

\section{INTRODUCTION}

In some ways, raising tax income is the government's most important function. Fundamentally, tax money is what allows the state to exist, paying everything from social programs to infrastructure investment [1]. As a result, revenue should be able to provide essential services such as security, education, and health care, as well as allow the government to participate in the financing of public investments. The government cannot support itself and the requirements of the public without tax money. As a result, it is frequently stated that taxes are the government's lifeblood. "This is true not only for the national government but also for the smallest government unit" (Dawilan, 2020) [2]. In line with the core concept of local autonomy, Section 129 of Republic Act 7160, also known as the "Local Government Code of 1991,"gives each Local Government Unit (LGU) the right to generate its own sources of revenue and collect taxes, fees, and charges according to the rules therein. The Local Government Code (LGC) lists the sources of revenue, and one of the local sources imposed by municipalities and cities is company tax. The LGC also specifies various tax rates and schedules that will be applied to each business based on its characteristics".

In LGUs, business taxes are the most important source of local revenue. Business taxes are often based on a company's total sales or receipts for the previous year. These taxes, as well as other fees and levies, begin to 
accrue on January 1st of each year and must normally be paid before the business license is given (Dawilan,2020). "According to the Bureau of Local Government Finance's (BLGF) Statement of Receipts and Expenditures (SRE) reports, the business tax has contributed the most to local revenues from 2009 to the third quarter of 2020" [4]. However, the revenue collected locally is insufficient to cover the local government's expenses. According to a 2016 analysis of LGU financial performance, LGUs are still 67 percent reliant on Internal Revenue Allotment (IRA), with local collection accounting for only 29 percent of total regular income (BLGF) [5]. The continued increase in local tax collection, on the other hand, demonstrates the success of local governments in collecting local revenues. The collection of company taxes has become an immense issue for each LGU as a result of the COVID-19 pandemic. In March 2020, the entire Luzon was placed under enhanced community quarantine to avert a rapid increase in COVID-19 cases. Only private businesses that provided basic requirements were permitted to operate. Executive Secretary's Memorandum, 2020). This leads to the temporary closure of many businesses, resulting in significant losses for business owners [6].Many firms survived the quarantine period by innovating and refining marketing techniques, but some were forced to close permanently due to health concerns and quarantine regulations. This season, on the other hand, represents an opportunity for online business. "The epidemic has hastened the transition to a more digital society and spurred changes in online shopping habits that are likely to have long-term consequences (UN Conference on Trade and Development, 2020)" [7]. In the fiscal year 2020, the BLGF takes into account the effects of a pandemic and authorizes LGUs to reduce the business tax collection target from Php126.19 billion to Php88.42 billion. LGUs exceeded their target in the third quarter of 2020, achieving a collection efficiency of 123 percent, or Php108.37 billion [8].

This was due to a variety of factors, including the relaxation of community quarantine restrictions, the restart of company activities, the extending of payment deadlines, and the introduction of online and alternative payment methods (BLGF). The outcomes of business establishment operations in 2020 will be used to assess business tax in 2021. Because of the pandemic and the slowdown in business activities in 2020, the BLGF has set the initial revenue target for business taxes for FY 2021 at Php97.75 billion. "The local government is expected to take the appropriate steps not just to help its citizens and business owners, but also to lessen the impact of the epidemic on local tax collection" [9]. "Determine the impact of COVID-19 on LGU Tax Collections, Assess the tax collection strategies implemented by LGUs during COVID-19 in terms of extensions of deadlines for payment of business tax, adoption of a digital facility for assessment and payment of business tax, and dissemination of information related to tax dues and extensions of deadlines and pro-rata payments" [9].

\section{METHODOLOGY}

The descriptive research design was utilized in this research. According to Calderon (2012), "descriptive method involves the outline, recording, analysis, and interpretation of the current nature, composition, or processes of phenomena that focuses on current conditions, or how an individual, group, or thing behaves or functions in the present." Relevant reports were obtained from the LGU's records or the BLGF's official website. The respondents were 25 employees of the Cabanatuan City Treasurer's Office who were purposefully chosen to perform direct and valid research ([10] as quoted by [11]). The instrument that was used to gather data was a questionnaire. The respondents were asked about the state of their business operations prior to the March 17, 2020, enhanced community quarantine in the first phase of the survey. The second section looked at the overall impact of the COVID-19 pandemic, including factors like company operations, financial flow, and raw material and workforce requirements. The impact of the COVID-19 pandemic on company operations was assessed using a Likert scale with responses ranging from (a) not affected, (b) slightly affected, (c) moderately affected, and (d) strongly affected. The survey and data collecting took place from June 7 to June 14, 2021. To summarize, characterize, and analyze the data acquired, descriptive statistical tools such as percentage and frequency distribution, tables, and graphs using Google Forms and Microsoft Excel were employed. 


\section{RESULTS AND DISCUSSION}

Table 1 shows that all respondents believed that LGU's business tax collections were affected by the COVID-19 pandemic.

Table 1. Reasons why business tax collection was affected by the COVID-19 pandemic

\begin{tabular}{lcc}
\hline & $\begin{array}{c}\text { No. of } \\
\text { Respondents }\end{array}$ & \% of respondents \\
\hline (a) temporary or permanent closure of businesses & 20 & $100 \%$ \\
(b) the limited operation resulted to lower-income of businesses & 15 & $80 \%$ \\
(c) noncompliance of businesses due to COVID-19 health protocol & 5 & $20 \%$ \\
(d) lack of information about tax policies of businesses & 0 & $0 \%$ \\
(e) limited operation of local government units & 9 & $40 \%$ \\
(f) health consideration for taxpayers & 15 & $80 \%$ \\
(g) others & 0 & $0 \%$
\end{tabular}

Table 1 shows that LGUs business tax collections were affected by temporary or permanent closure businesses. 80\% of the respondents also indicated that it was affected by limited operations of businesses and the health considerations of taxpayers. Moreover, $40 \%$ of the respondents stated that it was affected by limited operations of LGUs while $20 \%$ believed that it was because of noncompliance to health protocol.

Table 2. Extension of Deadlines for Payment

\begin{tabular}{|c|c|c|}
\hline Statement & $\begin{array}{l}\text { Weighted } \\
\text { Mean }\end{array}$ & $\begin{array}{c}\text { Verbal } \\
\text { Interpretation }\end{array}$ \\
\hline \multicolumn{3}{|l|}{ The extension of deadlines for payment... } \\
\hline $\begin{array}{l}\text { 1. helps the local government to achieve its collection target for the } \\
\text { previous year. }\end{array}$ & 3.8 & Strongly Agree \\
\hline $\begin{array}{l}\text { 2. gives the taxpayers a reasonable time to renew their business permits } \\
\text { and pay the corresponding tax dues. }\end{array}$ & 4 & Strongly Agree \\
\hline $\begin{array}{l}\text { 3. helps the local government in the proper implementation of minimum } \\
\text { health protocols during a pandemic. }\end{array}$ & 3.4 & Strongly Agree \\
\hline $\begin{array}{l}\text { 4. did not hinder the local government to achieve its target collections for } \\
\text { business tax resulted from waiver of interest, surcharge, and penalties. }\end{array}$ & 3.6 & Strongly Agree \\
\hline 5. applies to all taxpayers, regardless of the amount. & 3.6 & Strongly Agree \\
\hline General Weighted Mean & 3.68 & Strongly Agree \\
\hline
\end{tabular}

Table 2 shows that the majority of the respondents strongly agreed that the extension of deadlines for payment of business tax helps the LGUs to achieve their collection target for the previous year and properly implement minimum health protocols during a pandemic. Findings show that all respondents, with the highest weighted mean of 4.0, strongly agreed that it gives taxpayers a reasonable time to renew their business permits and pay the corresponding tax dues. Moreover, the majority of the respondents strongly agreed that it applies to all taxpayers regardless of the amount, and the waiver of interest, surcharges, and penalties did not hinder the LGUs to achieve their collection target. This means that the extension of deadlines for payment of business tax is an effective strategy to improve tax collections during the pandemic.

Table 3. Adoption of Digital Facility for Assessment and Payment of Business Tax

\begin{tabular}{ccc}
\hline Statement & $\begin{array}{c}\text { Weighted } \\
\text { Mean }\end{array}$ & $\begin{array}{c}\text { Verbal } \\
\text { Interpretation }\end{array}$ \\
\hline
\end{tabular}

The local government...

1. has the capacity to implement online transactions for assessment and

3.8 Strongly Agree

This article can be downloaded from here: www.ijaems.com 
payment of business tax.

2. adopted digital facility for business tax assessment and electronic payment (e-payment).

The adoption of online assessment and payment for business tax...

3. increase taxpayers' compliance relevant to pay taxes. pandemic while properly implementing minimum health protocols.

5. provides fast and accurate information, reduces the processing time, and improves the collection period.

General Weighted Mean
3.4 Strongly Agree

3.64 Strongly Agree

Table 3 reveals that the majority of the respondents strongly agreed that LGU has the capacity to implement a digital facility for the assessment and payment of business tax. The study shows that the implementation increases taxpayers' compliance to pay taxes and helps the government to achieve target collections during pandemic while properly implementing minimum health protocols. The lowest weighted mean of 3.4 verbally interpreted as "strongly agree" is still an indication that the majority of the respondents strongly agreed that the adoption of the digital facility is an effective strategy in improving tax collections during a pandemic.

Table 4. Dissemination of Information Related to Tax Dues and Extensions of Deadlines

\begin{tabular}{|c|c|c|}
\hline Statement & $\begin{array}{l}\text { Weighted } \\
\text { Mean }\end{array}$ & $\begin{array}{c}\text { Verbal } \\
\text { Interpretation }\end{array}$ \\
\hline \multicolumn{3}{|l|}{ The local government... } \\
\hline 1. maintains all the relevant information of the taxpayers. & 3.6 & Strongly Agree \\
\hline $\begin{array}{l}\text { 2. uses digital platforms to inform the taxpayers of their business tax dues, an } \\
\text { extension of deadlines of payments, and other policies. }\end{array}$ & 3.2 & Agree \\
\hline $\begin{array}{l}\text { 3. Actively reminding the taxpayers of their current tax dues and deadlines of } \\
\text { payment help the local government to achieve its target collections. }\end{array}$ & 3.4 & Strongly Agree \\
\hline $\begin{array}{l}\text { 4. Maintaining relevant information of taxpayers helps the local government } \\
\text { to disseminate information about tax dues and extension of deadlines for } \\
\text { payment during a pandemic. }\end{array}$ & 3.6 & Strongly Agree \\
\hline $\begin{array}{l}\text { 5. The use of digital platforms helps the local government to comply with the } \\
\text { minimum health protocols. }\end{array}$ & 3.6 & Strongly Agree \\
\hline General Weighted Mean & 3.48 & Strongly Agree \\
\hline
\end{tabular}

Table 4 shows that the majority of the respondents strongly agreed that maintaining all relevant information of taxpayers helps the LGU to disseminate information about tax dues and extension of deadlines for payment while the use of digital flatforms helps them to comply with the minimum health protocols during a pandemic. In addition, the survey shows that actively reminding the taxpayers of their current tax dues and deadlines of payment helps the LGU to achieve its target collections. However, it "uses digital platforms to inform the taxpayers of their business tax dues, an extension of deadlines of payments and other policies", with the lowest weighted mean of 3.2 verbally interpreted as "agree", which means that LGU is still using face to face delivery of information.

\section{CONCLUSIONS AND RECOMMENDATIONS}

Based on the results of the study, the researchers arrived at the following conclusions:

(a). The majority of the respondents believed that LGU's business tax collections were affected by the COVID-19 pandemic. (b). The LGUs business tax collections were

This article can be downloaded from here: $w w w . i j a e m s . c o m$

(C)2021 The Author(s). Published by Infogain Publication. greatly affected by temporary or permanent closure businesses. (c). The majority of the respondents strongly agreed that the extension of deadlines for payment of business tax helps the LGUs to achieve their collection target for the previous year and properly implement minimum health protocols during a pandemic.(d). The 
majority of the respondents strongly agreed that LGU has the capacity to implement digital facilities for assessment and payment of business tax and also the implementation increases taxpayers' compliance to pay taxes and helps the government to achieve target collections during pandemic while properly implementing minimum health protocols.(e). The majority of the respondents strongly agreed that maintaining all relevant information of taxpayers helps the LGU to disseminate information about tax dues and extension of deadlines for payment while the use of digital platforms helps them to comply with the minimum health protocols during a pandemic. In line with the findings and conclusions, the following was recommended: LGUs should accelerate the shift of faceto-face to online transactions [12]. Provide a platform that taxpayers can see their profile, how much they should pay, deadline of payment, announcements and etc. This can help tax collection carry on amidst this crisis. Also, this also helps to ensure the safety of both taxpayers and collectors.

\section{REFERENCES}

[1] Afschrift, Thierry, (2021), Taxation during a Pandemic: Challenges and Perspectives. Retrieved from https://www.worldfinance.com/strategy/taxation-in-timesof-a-pandemic-challenges-andperspectives?fbclid=IwAR0xQL14_e_A6xGcQu_e8vNS5 ARFsx7H8YbQLEwUxVcsKiJWPmVO5h6Ipog

[2] Dawilan, Fulvio, D., (2020), Issues on Extended Deadlines in Payment of Local Taxes Clarified. Retrieved from https://businessmirror.com.ph/2020/06/16/issues-onextended-deadlines-in-payment-of-local-taxes-clarified/

[3] Official Gazette of the Philippines. (1991, October, 10). The Local Government Code of the Philippines. Retrieved from https://www.officialgazette.gov.ph

[4] Bureau of Local Government Finance. (2017). LGUs Exceed FY 2020 Own-Source Revenue Targets. Retrieved from https://blgf.gov.ph

[5] Bureau of Local Government Finance. (2017). LGU Financial Performance. Retrieved from https://blgf.gov.ph/wpcontent/uploads/2017/10/Consolidated-LGU-FinancialPerformance-1.pdf

[6] Official Gazette of the Philippines. (2020, March, 16). Memorandum from the Executive Secretary: Community Quarantine over the Entire Luzon and Further Guidelines for the Management of the Coronavirus Disease 2019 (COVID-19) Situation. Retrieved from https://www.officialgazette.gov.ph

[7] United Nations Conference on Trade and Development. (2020). COVID-19 has changed online shopping forever, survey shows. Retrieved https://unctad.org/news/covid-19has-changed-online-shopping-forever-survey-shows

[8] Revenue Statistics in Asian and Pacific Economies. (2020). Tax Policy and Administration Responses to COVID-
19.Retrieved from https://www.oecdilibrary.org/sites/a06bffa0en/index.html?itemId $=\% 2$ Fcontent $\% 2 \mathrm{Fcomponent} \% 2 \mathrm{Fa} 06$ bffa0-

en\&fbclid=IwAR15JQ6gZbsd2BGmDsHsoNd4Xfr30li3nc 5vzQs4yF-NuCpuzGlEulzUsVg

[9] NTRC Tax Research Journal. (2020). Best Practices by Selected Local Government Units to Combat Coronavirus Disease 2019 (Vol. XXXII.5 September-October 2020). Retrieved from https://ntrc.gov.ph/images/journal/2020/j20200910b.pdf?fb clid=IwAR0acqTzRuNeSTrn9Ypq4G4WMGpduItlJSB4CHzRUhAEl_IV0RMDIZATrw

[10] Subia, G.S.(2018). Comprehensible Technique in Solving Consecutive Number Problems in Algebra. Journal of Applied Mathematics and Physics, 6, 447-457. https://doi.org/10.4236/jamp.2018.63041.

[11] Abelardo, L., Lomboy, M., Lopez, C., Balaria, F., \& Subia, G. (2019). Challenges Encountered by the National High School Teachers in Doing Action Research. International Journal of English, Literature and Social Science (IJELS). Vol-4, Issue-4, Jul $\quad$ - Aug 2019 https://dx.doi.org/10.22161/ijels.4418 ISSN:2456-7620.

[12] Mina, J.C., Subia, G.S.,Barlis, P.T., Tuliao, R.C. and Pastorfide, P.M. (2020). Inclinations of Engineering and Marketing Management Students to Engage in Online Learning Technology Amidst the COVID-19 Pandemic. Technology Reports of Kansai University, ISSN: 04532198, Volume 62, Issue 09

This article can be downloaded from here: www.ijaems.com 